\title{
ENGLISH LANGUAGE EDUCATION FOR YOUNG ADULTS: A PEDAGOGICAL RESIDENCY EXPERIENCE
}

\author{
Ensino De Língua Inglesa Para Jovens E Adultos: Uma Experiência Na Residência \\ Pedagógica
}

Desafios

\begin{tabular}{|lllllll} 
Enseñanza Del Idioma Inglés Para & Jóvenes & $Y$ & Adultos: & $\begin{array}{c}\text { Artigo Original } \\
\text { Original Article } \\
\text { Artículo Original }\end{array}$ \\
Una Experiencia En La Residencia Pedagógica & & & & &
\end{tabular}

Miliane M. C Vieira' ${ }^{1}$, Vinicius Canafístula de Oliveira², Ailla Caroliny Gomes Rodrigues Reis $^{3}$, Davi Pereira Gomes ${ }^{4}$.

${ }^{1}$ Docente do Curso de Graduação em Letras - Língua Inglesa e Literaturas, Universidade Federal do Tocantins UFT, Araguaína, Tocantins, Brasil.

${ }^{2}$ Acadêmico, Letras-Língua Inglesa e Literaturas, UFT- Universidade Federal do Tocantins, Araguaína-Campus Cimba, Brasil.

${ }^{3}$ Acadêmica, Letras-Língua Inglesa e Literaturas, UFT- Universidade Federal do Tocantins, Araguaína-Campus Cimba, Brasil.

${ }^{4}$ Professor da Educação Básica, Secretaria de Estado da Educação, Juventude e Esportes do Tocantins - SEDUC, Araguaína, Tocantins, Brasil.

Artigo recebido em 03/04/2020 aprovado em 20/04/2020 publicado em 20/04/2020.

\section{INTRODUCTION}

This work aims to relate to the teaching of a foreign language in a public adult school, analyzing educational documents with teaching practice for students of a public school, in a peripheral neighborhood of the city of Araguaína-To. When focusing the school curriculum, the public of students enrolled is often identified as an economically vulnerable audience.

Referring to resources to teach a foreign language, we can say there is a lack of resources in the school, because it has no pedagogical materials to assist students in their learning process. In view of the fact, the teaching of young adults does not have didactic material for any other discipline. Besides, during the English lessons, we met students who have no reference to the English language and with no prospect of use it beyond the classroom.

\section{METHODOLOGIES AND MATERIALS}

While we were teaching at this school, we had a preceptor who helped us any time we needed. He was always coming and going into our lessons to check if we were going on well. My partner and I used to talk to him about the contents and the grades of the students. He was our preceptor since the beginning of the pedagogical residency. He tried to prove us we were capable of teaching independently. However, it was difficult to follow up the class being just an intern/resident, sometimes. 
We had to face problems with attendances. What should be the grade of a student who came only once in our lessons? And it was a problem to the other teachers, too. Our preceptor always gave us the chance to share our ideas and activities. He was very receptive with our suggestions and teaching activities. And this gave us a chance to see how we were improving our teaching along the year.

While teaching this semester, my conclusions were that the Young Adult Education needs more attention from the government regarding didactic material. These students miss some books to study, even by themselves. For the English subject there is no book or any other material to work with the class. I missed one speaker for showing how a conversation in English is. Most of the times I need to take my speaker to the classroom, but if I did not have my own? How would the school solve the problem?

The materials we were working with in class were all made for me and my partner, without any help from the school. We worked with what we had, "but, it is in the face of dissatisfaction with a teaching situation that a transformation can be considered" (MAGALHAES, 2009. p, 182). Thus, we worked with a little we have and we worked as well as possible.

It is possible to bring to a reflection that it is not essential to have all the teaching

\footnotetext{
${ }^{1}$ Mas, é diante de uma insatisfação frente a uma situação de ensino que se pode considerar um transformação. (MAGALHÃES, 2009, p. 182)
}

materials in the world to do any better, but its absence does not make work impossible. As Magalhães claims

The problems that may occur in the transposition of scientific knowledge to the pedagogical texts are the lack of legitimacy of the chosen theory of reference and the possible negative effects on the use of certain notions and concepts, such as the reorganization and attribution of new meanings to the transposed elements of the scientific knowledge ${ }^{2}$ (MAGALHAES, 2009, p. 182)

The author makes a reflection about theory and reality when she says "lack of legitimacy of the chosen theory of reference." (MAGALHÃES, 2009, p. 182). It means the need for knowing how to choose the correct theory for working with the reality.

\section{RESULTS AND DISCUSSIONS}

This reflective writing focuses on Youth and Adult Education - EJA. A reflection about the lessons given in an educational center, as needy as a state public school. Most students look for EJA to complete High School and find a better quality job. Not all of them are concerned with really taking advantage of the opportunity offered to them. It is, most of times, the teacher's duty to try to instigate in these students the interest of

\footnotetext{
${ }^{2}$ Os problemas que podem ocorrer na transposição do saber cientifico para os textos pedagógicos são a falta de legitimidade da teoria de referencia escolhida e os possíveis efeitos negativos no uso de determinadas noções e conceitos, como a reorganização e atribuição de novos significados aos elementos transpostos do saber científicos. (MAGALHÃES, 2009, p. 182)
} 
knowing the contents presented to them in daily teaching.

The process of learning a foreign language necessarily involves the perception that it is the acquisition of a complex cultural product. This learning, started in elementary school, implies the completion of well-delineated stages that, in high school, will culminate in the mastery of skills and abilities that will allow the student to use this knowledge in multiple spheres of their personal, academic and professional life. (BRASIL, PCN +, 2002, page 93$)^{3}$

There is no doubt that English language teaching in schools does not have all the prepared teachers need. What I could see as a resident is that in addition to not having a quality education in elementary school, public schools have many activities to be done throughout the year and the time and investment for these are definitely inappropriate. Thus, the pedagogical residency made me understand that students do have a desire to learn a language, a new culture. The problem is how we captivate these students. What to do so that these students dedicate themselves to studies to achieve the goals we planned at the beginning of class.

Youth and Adult Education open classes every six months. As it is a faster training method, we have much less time to

3 O processo de aprendizagem de uma língua estrangeira envolve obrigatoriamente a percepção de que se trata da aquisição de um produto cultural complexo. Esse aprendizado, iniciado no ensino fundamental, implica o cumprimento de etapas bem delineadas que, no ensino médio, culminarão com o domínio de competências e habilidades que permitirão ao aluno utilizar esse conhecimento em múltiplas esferas de sua vida pessoal, acadêmica e profissional. (BRASIL, PCN+, 2002, pág. 93) execute the lesson plan proposed in the Pedagogical Political Project. A content that should be worked on in a year is worked in such a way that we cannot fully develop into it. Even with so many difficulties, it is possible to reach an even satisfactory result, considering the particularities of each student, the social context that they are inserted and the lack of structure for a quality education.

The foreign language occupies a privileged position in the curriculum as it serves as a "tool" for all other subjects, facilitating the articulation between areas and offering multiple supports for various activities and projects. What happens in interdisciplinary projects, albeit in a simulated way, is an anticipation of what will happen in the student's future social life, in the world of work and in the academic sphere, if her/his studies are to be continued. $\left(\right.$ BRASIL, PCN +, 2002, page 94) ${ }^{4}$

As reported on $\mathrm{PCN}+(\mathrm{BRAZIL}$, 2002), having a curriculum containing the English language studies, allows the student to have certain privileges especially in the job market, which is the interest of these students.

\section{CONCLUSION}

\footnotetext{
${ }^{4}$ A língua estrangeira ocupa posição privilegiada no currículo por servir como "ferramenta" a todas as outras disciplinas, facilitando a articulação entre áreas e oferecendo múltiplos suportes para várias atividades e projetos. O que ocorre nos projetos interdisciplinares, ainda que de modo simulado, é uma antecipação do que acontecerá na futura vida social do aluno, no mundo do trabalho e no âmbito acadêmico, se for prosseguir seus estudos. (BRASIL, PCN+, 2002, pág. 94)
} 
Even with all the concerns related to the English Teaching studies to Youth and Adults Education, we could say some change has occurred along our time at this school. In the end, we, residents, together with the tutor professor from the University and the school preceptor could organize a row of three lectures to inform students about the possibilities they had in front of them if they learned the English language and if they concluded their High school. Both could be important for their curriculum and professional development.

I am not afraid to say that, when we teachers believe and invest in our students, they correspond. These students have shown great interest both in entering higher education and in starting a technical or vocational course.

Besides, tthroughout the term, the need to use a foreign language in the job market was developed with students, being a possibility of access to the world.

\section{REFERENCES}

BRASIL. Orientações Educacionais

Complementares Aos Parâmetros
Curriculares Nacionais $(\mathrm{PCN}+$ Ensino Médio). Linguagens, Códigos e suas Tecnologias. Brasília: MEC, 2002.

MAGAlHÃeS, Maria Cecília C. A formação do Professor como um Profissional Crítico: linguagem e reflexão. Campinas, SP: Mercado das Letras, 2009 